\title{
Erratum to: Infrastructures for Virtual Enterprises
}

\author{
Luis M. Camarinha-Matos ${ }^{1}$ and Hamideh Afsarmanesh ${ }^{2}$ \\ 1 New University of Lisbon, Portugal \\ 2 University of Amsterdam, The Netherlands
}

\section{Erratum to: \\ L.M. Camarinha-Matos and \\ H. Afsarmanesh (Eds.) \\ Infrastructures for Virtual Enterprises \\ DOI: $10.1007 / 978-0-387-35577-1$}

The book was inadvertently published with an incorrect name of the copyright holder. The name of the copyright holder for this book is: (c) IFIP International Federation for Information Processing. The book has been updated with the changes.

The updated original online version for this book can be found at DOI: $10.1007 / 978-0-387-35577-1$ 